DOI: $10.14720 /$ aas.2016.107.1.06

Agrovoc descriptors: fragaria ananassa; protected cultivation; irrigation systems; trickle irrigation; cost benefit analysis; emitters (irrigation)

Agris category code: F06, f08

\title{
Technical and economical evaluation of tape drip and drip line irrigation systems in a strawberry greenhouse
}

\author{
Soghra HOSSEINIAN ${ }^{1}$, Mohammadreza KHALEDIAN ${ }^{1, *}$, Mohammad Hassan BIGLOUEI ${ }^{1}$, Parisa \\ SHAHINROKHSAR ${ }^{2}$
}

Received October 07, 2015; accepted February 11, 2016.

Delo je prispelo 07. oktobra 2015, sprejeto 11. februarja 2016.

\begin{abstract}
This study was done in a strawberry greenhouse to examine the technical and the economical evaluation of two drip irrigation systems including the tape and the drip line in the northern part of Iran. The result showed that all of the technical indices with tape were higher than drip line, and due to statistical analysis reveal a significant difference $(\mathrm{P}<0.05)$. Yield and water productivity (WP) with tape were higher than drip line $(\mathrm{P}<0.05)$. Benefit per drop (BPD) and net benefit per drop (NBPD) with tape were higher than drip line. Net present value, internal rate of capital return and benefit to cost ratio in drip line were higher than tape. In general, regarding technical evaluation tape was better than drip line, besides according to the economical evaluation the drip lines were better than tape.
\end{abstract}

Key words: drip irrigation, emitter efficiency, benefit to cost ratio, strawberry (Fragaria $x$ ananassa Duchesne)

\section{IZVLEČEK}

OVREDNOTENJE TEHNIČNE USTREZNOSTI IN EKONOMIČNOSTI DVEH SISTEMOV KAPLJIČNEGA

NAMAKANJA (z namakalnim trakom in z linijo s kapljači) JAGODNJAKA (Fragaria $x$ ananassa Duchesne) V RASTLINJAKU

Raziskava je bila opravljena $\mathrm{z}$ namenom ovrednotenja tehnične ustreznosti in ekonomičnosti dveh sistemov kapljičnega namakanja: $\mathrm{z}$ namakalnim trakom in $\mathrm{z}$ linijo $\mathrm{s}$ kapljači pri gojenju jagodnjaka $\mathrm{v}$ rastlinjaku, $\mathrm{v}$ severnem delu Irana. Rezultati so pokazali, da so bili pri sistemu namakanja $\mathrm{z}$ namakalnim trakom vsi tehnični kazalci boljši kot v sistemu z linijo s kapljači in statistične analize kažejo značilno razliko $(\mathrm{P}<0.05)$. Pridelek in produktivnost vode (WP) sta bila večja pri sistemu $\mathrm{z}$ namakalnim trakom kot $\mathrm{z}$ linijo $\mathrm{s}$ kapljači $(\mathrm{P}<0.05)$. Prihodek na $\mathrm{m}^{3}$ vode $(\mathrm{BDP})$ in dobiček na $\mathrm{m}^{3}$ vode (NBDP) sta bila večja $\mathrm{v}$ sistemu $\mathrm{z}$ namakalnim trakom kot $\mathrm{v}$ sistemu linija $\mathrm{s}$ kapljači. Neto sedanja vrednost, interna stopnja donosnosti kapitala in indeks donostnosti so bili večji $\mathrm{v}$ sistemu linije $\mathrm{s}$ kapljači kot $\mathrm{v}$ sistemu $\mathrm{z}$ namakalnim trakom.V splošnem je bil tehnološko sistem z namakalnim trakom boljši kot linija s kapljači, a pri ovrednotenju ekonomičnosti je bilo ravno obtratno.

Ključne besede: kapljično namakanje, učinkovistost kapljača, indeks donosnosti, jagodnjak (Fragaria $x$ ananassa Duchesne)

\section{INTRODUCTION}

With water resources deficiency, optimum use of water in the agricultural sections is very important. In countries that face water deficiency, producing crops with minimum water consumption is very important. Iran is located in an arid and semiarid zone and water is a limiting factor in crop

\footnotetext{
Water Engineering Department, Faculty of Agricultural Sciences, University of Guilan, Rasht, Iran Khaledian@guilan.ac.ir

Agricultural and Natural Resources Research Institute of Guilan, Rasht, Iran
} 
production. In recent years due to water resources deficiency, greenhouse cultivation of products on one hand and applying drip irrigation on the other hand have received a lot of attention. Currently the best irrigation method for greenhouse productions is drip irrigation which along with fertigation increases water productivity and fertilizers efficiency and improves yield quantity and quality. Due to the expansion of drip irrigation methods in greenhouses being familiar with the designing principles, performance and proper management of irrigation systems in greenhouses seems very indispensable. Beside expansion of drip irrigation systems in greenhouses, system quality should be considered. By technical evaluation of drip irrigation systems, distribution uniformity indices, emitter efficiency, discharge variations and variation coefficients of emitters should be measured. Then system performance can be determined and by proposing relevant solutions system defects can be eliminated which results in improving and maximizing system performance. The high investment of installation and implementation of drip irrigation systems and focusing on their profitability justify the importance of economical evaluation of irrigation systems. Therefore, revenues, costs and net income of drip irrigation in greenhouse would be calculated and then the most cost effective irrigation system in greenhouse can be determined. In recent years the use of tape drip irrigation and drip lines in greenhouse has become common. Both systems have advantages and disadvantages and have caused doubt in experts and farmers on selecting the desired system.

According to Picha (1999) tapes of drip irrigation for strawberry production is optimum. Ortega et al (2002) evaluated 100 drip irrigation systems and reported that the amount of distribution uniformity in systems was good and estimated the average of emitter uniformity (EU) as $84.3 \%$. Noshadi and Ghaemi (2012) evaluated drip irrigation systems in 124 orchards in Fars province, Iran and calculated the amounts of application efficiency of low quarter (AELQ) and potential efficiency of low quarter (PELQ) being of 72 and $65 \%$, respectively. Cetin et al (2004) evaluated drip irrigation in olive gardens of Turkey and used net present value index and reported that drip irrigation is profitable and have the economic justification. Azizi (2007) by examining three parameters including: net present value, internal rate of capital return and benefit to cost ratio, reported that banana cultivation and mix cultivation of banana and asparagus have not got any economic justification in Kishestan Greenhouse Complex, Guilan province, Iran, whereas, the production of some other plants such as cut flowers and vegetables have economic justification. Rhea et al (2001) obtained net profit for tomato and tobacco as 10372.52 and 12121.22 US $\$ \mathrm{ha}^{-1}$, respectively.

As far as in recent studies have been dedicated to the technical and the economical evaluations of irrigation systems in the fields and gardens separately according to the product itself, therefore, the technical and the economical evaluations of the aforementioned irrigation systems have been the center of attention. The results of this study would lead to a better status along with developing the drip line system, improving water consumption to an acceptable level, and finally reducing the production costs in the greenhouses. Moreover, it would be applied by farmers, the experts on irrigation system designing as well as those who are interested in establishing a greenhouse.

\section{MATERIALS AND METHODS}

This study was done in a strawberry greenhouse in Kishestan Greenhouse Complex located in Some'sara, Guilan province in the northern part of Iran (Figure 1) in 2014-2015. The approximate area of greenhouse was $500 \mathrm{~m}^{2}$ (the width of greenhouse was $9 \mathrm{~m}$ and the length of that was 55 $\mathrm{m})$. This study was done in a completely randomized design. The physical and chemical characteristics of the soil are presented in Tables 1 and 2 . 


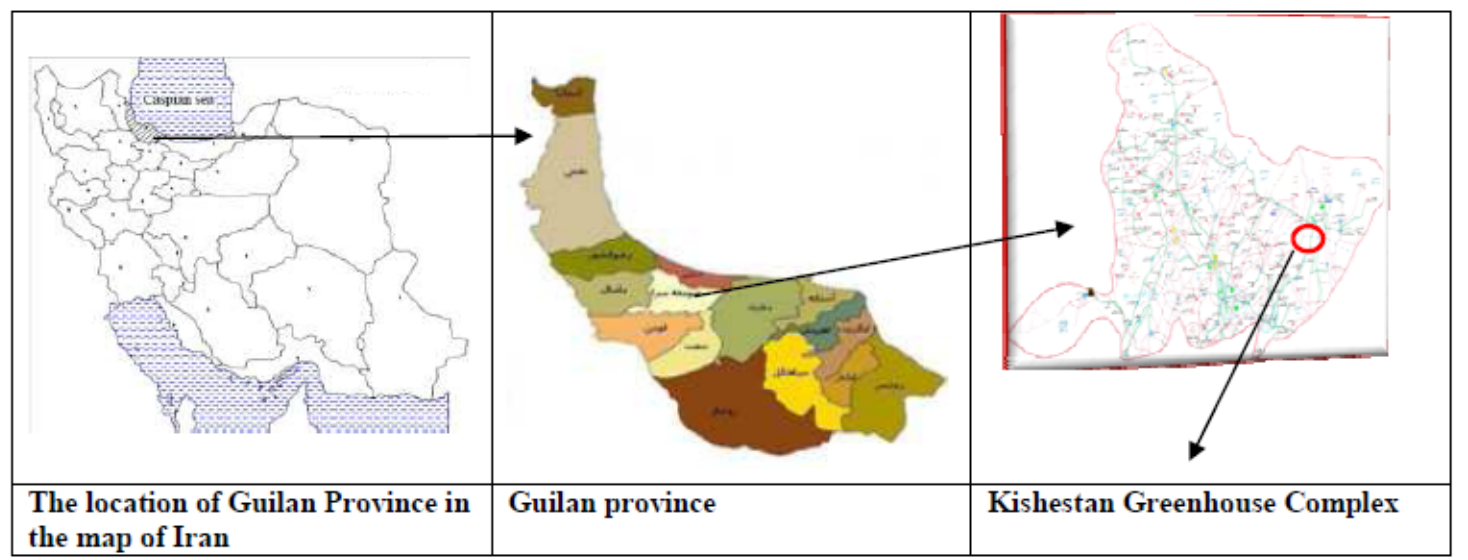

Figure 1: The location of Kishestan Greenhouse Complex in the Guilan province and in Iran

Table 1: Physical characteristics of the soil in Kishestan Greenhouse Complex (Iran)

\begin{tabular}{cccccll}
\hline $\begin{array}{c}\text { Sand } \\
(\%)\end{array}$ & $\begin{array}{l}\text { Silt } \\
(\%)\end{array}$ & $\begin{array}{c}\text { Clay } \\
(\%)\end{array}$ & Soil texture & $\begin{array}{l}\theta \text { s* } \\
(\%)\end{array}$ & $\begin{array}{l}\text { Field } \\
\text { capacity (\%) }\end{array}$ & $\begin{array}{l}\text { Wilting } \\
\text { point }(\%)\end{array}$ \\
\hline 66 & 20 & 14 & Sandy Loam & 51.51 & 20.44 & 11.44 \\
\hline
\end{tabular}

*volumetric saturated water content

Table 2: Chemical characteristics of the soil in Kishestan Greenhouse Complex (Iran)

\begin{tabular}{|c|c|c|c|c|c|c|c|c|c|c|c|}
\hline \multirow{2}{*}{$\begin{array}{l}\text { Cations } \\
\text { sum }\end{array}$} & \multicolumn{4}{|c|}{ Cations $\left(\mathrm{meq} \mathrm{l}^{-1}\right)$} & \multirow{2}{*}{$\begin{array}{l}\text { Anions } \\
\text { sum }\end{array}$} & \multicolumn{4}{|c|}{ Anions (meq $~^{-1}$ ) } & \multirow[b]{2}{*}{$\mathrm{pH}$} & \multirow{2}{*}{$\begin{array}{l}\mathrm{EC} \\
(\mathrm{mmhos} \\
\left.\mathrm{cm}^{-1}\right)\end{array}$} \\
\hline & $\mathrm{Mg}^{2+}$ & $\mathrm{Ca}^{2+}$ & $\mathrm{Na}^{+}$ & $\mathrm{K}^{+}$ & & $\mathrm{CO}_{3}^{2}$ & $\mathrm{HCO}_{3}^{-}$ & $\mathrm{Cl}^{-}$ & $\mathrm{SO}_{4}^{-2}$ & & \\
\hline 44.1 & 14.1 & 15.3 & 14.7 & - & 44.4 & - & 11.3 & 17.8 & 15.3 & 7.9 & 403 \\
\hline
\end{tabular}

Irrigation water was classified according to the Wilcox classification in $\mathrm{C} 2 \mathrm{~S} 1$ class (C2 i.e. EC: 250-750 mmhos $\mathrm{cm}^{-1}$ and S1 i.e. SAR: 0-10). Chemical analysis of irrigation water showed the deposition risk of calcium carbonate and calcium sulfate in irrigation systems is absent. In general, irrigation water quality parameters were in an acceptable range. Soil preparation has been done using a plough and then a disc. Six plots have been prepared and in each one 8 furrows have been prepared to transplant strawberry seedlings. Irrigation water for the greenhouse has been provided by a 2000-liter-tank from Pasikhan River and pumped to the irrigation system. To supply necessary pressure in the irrigation system a CAM100 Pentax pump has been applied with a discharge of 10-50 $1 \mathrm{~min}^{-1}$. In order to prevent tapes and drip lines clogging a disc filter (130 micron) was installed. Polyethylene pipes with $32 \mathrm{~mm}$ of diameter for the main pipe, $25 \mathrm{~mm}$ as the manifold and $16 \mathrm{~mm}$ as tapes and drip lines were used. Water was transferred from the pump to the main pipe having a length of $5 \mathrm{~m}$. Six manifolds were branched from the main pipe. In the beginning of each manifold a valve was installed to adjust the amount of inflow to the system, and then the required pressure in the system was controlled by placing a manometer and a pressure regulator after the electro-pump. Drip lines and tapes were branched from the manifolds. In the beginning of every drip lines and tapes, a valve was installed in order to stop the water from being wasted. Inflow water volume was measured by a flow-meter. The soil surface was covered with black polyethylene mulch to keep away weed and to preserve soil moisture. The strawberry seedlings ('Selva' variety, a common variety in the region) were transplanted to the greenhouse in the beginning of December and have been planted in two-row lines. Required fertilizers and pesticides were applied in both of the treatments as recommended by the expert and used by the farmers in the region. 
Greenhouse environmental factors such as temperature and heat were controlled by thermometer, heater and thermostat. The treatments were two drip irrigation systems including tape and drip line with three replications. Tapes with a diameter of $16.1 \mathrm{~mm}$, a discharge of $8 \mathrm{l} \mathrm{h}^{-1} \mathrm{~m}^{-1}$, an emitter intervals of $20 \mathrm{~cm}$ and drip lines with a diameter of $16 \mathrm{~mm}$, a discharge of $2.21 \mathrm{~h}^{-1}$, an emitter intervals of $40 \mathrm{~cm}$ both of them under $100 \mathrm{kPa}$ of pressure have been applied which were manufactured by AZUD company and have been provided for this study.

For the technical evaluation, coefficient of variation (CV) for emitter manufacturing, coefficient of uniformity $\left(\mathrm{CU}_{1}\right)$ for water distribution at the soil surface, coefficient of uniformity in soil $\left(\mathrm{CU}_{2}\right)$ for water distribution in the soil, distribution uniformity (DU) for water distribution at the soil surface, statistical coefficient of uniformity (UC) for water distribution at the soil surface which has a statistical meaning and depends on the standard error and the average of dripper discharge in a drip irrigation system, emission uniformity (EU), a measure of the uniformity emissions from all the drippers within a drip irrigation system, and efficiency of application (EA) for irrigation water in a drip irrigation system have been measured. DU is related to CU1 and DU $=100-1.59(100-C U 1)$ whereas EU is the field test emission uniformity $(\%)$ and is defined as the ratio of the average rate of discharge of the lowest one-fourth of the field data emitter discharge reading to the average rate of all the emitters checked in the field (Merriam and Keller, 1978).

In order to determine $\mathrm{CV}$ in drip line, emitter discharge of 50 emitters at a pressure of 50, 80, 100 and $160 \mathrm{kPa}$ were measured and used to calculate the mean discharge i.e. emitter discharge was calculated as the ratio of measured water volume in the elapsed time, with embedded graduated cylinders below emitters the volume of water was measured within a known time. For tape, emitter discharge of each meter of tape at a pressure of $50,80,100$ and $120 \mathrm{kPa}$ were measured, a pressure higher than $120 \mathrm{kPa}$ would cause ruptures in the tape so the maximum pressure was $120 \mathrm{kPa}$. Measurements were carried out in the first and last one meter of the tape as well as in one meter of the one third and two thirds of tape length (Merriam and Keller, 1978; Shojaeian and Ghaemi, 2010).

To determine other technical indices, 2-3 meters from the beginning of the pipe was waived due to discharge changes. Four emitters at first, a third, two-thirds and at the end of the drip line length were selected [Juana et al, 2007]. In the tapes, four 1-meter sections were selected. An hour after the start of the system and reaching the hydraulic equilibrium in the system, sampling containers were placed at designated locations and the amount of irrigation water was measured in a known time. To evaluate the uniformity of water distribution in the soil, 24 hours after irrigation soil samples were taken with an auger in sampling locations near the emitter and in the root zone $(0-15 \mathrm{~cm})$ and weighted average of soil moisture content was determined (Juana et al, 2007). All measurements were replicated three times.

For the economical evaluation yield, water productivity indices (WP, BPD and NBPD), net present value (NPV), internal rate of capital return (IRR) and benefit to cost ratio $(\mathrm{B} / \mathrm{C})$ were determined.

Strawberry harvest was done from mid-March to mid-June for a period of four months and the average yield of the iterations (three replications in each treatment) and total harvested yield during this period was considered as the strawberry yield in the greenhouse.

The statistical analysis was done using SPSS software package version 18, and two sample t-test has been done. The data has been evaluated by the Kolmogorov-Smirnov test. The variance has been examined by Leven test.

\section{RESULTS AND DISCUSSION}

$\mathrm{CV}$ for drip lines under pressures of 50, 80, 100 and $160 \mathrm{kPa}$ in average was calculated as 0.08 and for tape under pressures of 50,80, 100 and $120 \mathrm{kPa}$ in average was calculated as 0.07 (tables 3 and 4). 
The CV in tape was less than drip lines. According to American Society of Agricultural Engineering (ASAE) classification (Alizadeh, 2011), drip lines were in the medium class $(0.07<\mathrm{CV}<0.11)$ and tapes were in the excellent class $(\mathrm{CV}<0.1)$. The study of Shojaeian and Ghaemi (2010) showed that the coefficients of variation in tape was less than drip line; therefore, this system improved DU at the soil surface as well as in the soil profile.

$\mathrm{CV}$ in drip lines under $100 \mathrm{kPa}$ of pressure was 0.07 and classified in the medium class. Sadrghaen et al (2012) and Umara et al (2011) reported that $\mathrm{CV}$ in drip lines according to ASAE classification was in the medium class which is in agreement with the results of the present study. The coefficient of variation in tape under $100 \mathrm{kPa}$ of pressure was calculated as 0.03 that was classified in the excellent class. Duta (2008), HasanzadehArnayi and Fathi (2012) and Karimi et al (2004) determined the coefficient of variation in tape and classified it in the excellent class according to ASAE classification being in agreement with our results. Coefficient of variation under $100 \mathrm{kPa}$ of pressure in tape was less than drip lines. Therefore, it can be concluded that the coefficient of variation under $100 \mathrm{kPa}$ of pressure in tape had a higher uniformity than drip lines. Coefficient of variation in drip lines increased by increasing the pressure from 100 to $160 \mathrm{kPa}$ and by reducing the pressure from 100 to $80 \mathrm{kPa}$. Coefficient of variation did not change by reducing the pressure from 100 to $50 \mathrm{kPa}$. As a result, it can be concluded that drip lines under $100 \mathrm{kPa}$ of pressure had higher distribution uniformity than 80 and $160 \mathrm{kPa}$. The coefficient of variation in tape increased by increasing the pressure from 100 to $120 \mathrm{kPa}$. Besides, the coefficient of variation increased by decreasing the pressure from 100 to 80 and $50 \mathrm{kPa}$ that causes non uniformity in less and higher pressures than the nominal pressure $(100 \mathrm{kPa})$. Generally, the distribution uniformity in both systems under $100 \mathrm{kPa}$ of pressure was more than the other pressures. This finding is similar to the results of Shojaeyan and Ghaemi (2010).

Table 3: Coefficient of variation for emitter manufacturing in drip lines in Kishestan Greenhouse Complex (Iran) experiment $(\mathrm{N}=3)$

\begin{tabular}{ccccc}
\hline Pressure $(\mathrm{kPa})$ & 50 & 80 & 100 & 160 \\
\hline $\mathrm{CV}$ & 0.07 & 0.11 & 0.07 & 0.08 \\
Classification & average & bad & average & average \\
\hline
\end{tabular}

Table 4: Coefficient of variation for emitter manufacturing in tape in Kishestan Greenhouse Complex (Iran) experiment $(\mathrm{N}=3)$

\begin{tabular}{ccccc}
\hline Pressure $(\mathrm{kPa})$ & 50 & 80 & 100 & 120 \\
\hline $\mathrm{CV}$ & 0.13 & 0.06 & 0.03 & 0.05 \\
Classification & good & great & great & great \\
\hline
\end{tabular}

Calculated uniformity coefficients of the two irrigation systems are presented in table 5 . Coefficient of uniformity (CU1) in drip lines and tape were calculated as 91.22 and $97.38 \%$, respectively that according to Bralts's method of classification (Bralts, 1986), both irrigation systems are in the excellent class. Statistical analysis showed that there is a significant difference between those two irrigation systems
(P<0.01). Safi et al (2007), Tagar et al (2010), Duta (2008), Ghaemi et al (2008) and Karimi et al (2004) estimated the amount of uniformity coefficients $\left(\mathrm{CU}_{1}\right)$ from 95 up to $98 \%$ in tape that is in agreement with the results of the current study. Distribution uniformity in soil $\left(\mathrm{CU}_{2}\right)$ in drip lines and tape were calculated as 81.40 and $92.45 \%$ respectively, showing that the two irrigation systems have a significant difference 
$(\mathrm{P}<0.01)$. Distribution uniformity in soil on tape was more than drip lines which is similar to the results of the coefficient uniformity in these two systems. Shojaeyan and Ghaemi (2010) reported a better water distribution in tape than drip line at soil surface and in the soil profile. DU was calculated 86.04 in drip lines and $95.76 \%$ in tape. According to Noshadi and Ghaemi (2012) in valuable plants with shallow root system such as strawberry, the most economical system should have a high uniformity and in other words more than $80 \%$, and according to GhassemzadehMojaveri (1990) a DU of $50 \%$ is acceptable. Consequently, both irrigation systems in terms of distribution uniformity are appropriate, however, statistical analysis showed a significant difference in distribution uniformity between the two systems $(\mathrm{P}<0.01)$. The results of the present study are in the range of distribution uniformity reported by Umara et al (2011), Hanson and Bendixen (2004) and Ashiri et al (2013) which varies between 81 to $96 \%$. Statistical coefficient (UC) in both drip lines and tape systems calculated as 93.24 and $96.72 \%$, respectively. According to Bralts's classification and ASAE classification both systems are in the excellent class but statistical analysis showed a significant difference between these two systems $(\mathrm{P}<0.05)$.

EU was estimated in drip lines and tape systems as 84.11 and $95.84 \%$, respectively and statistical analysis showed that there is a significant difference $(\mathrm{P}<0.05)$ through which according to Merriam and Keller (1978) and Bralts (1986), drip lines systems were in the good class and tape irrigation system was in the excellent class. According to Erida classification (BamdadMachiani et al., 2014) drip lines was in the acceptable and tape irrigation system was in the excellent class and according to Capara and Scicolone (1998) classification both of the systems have a high EU. So totally according to Merriam and Keller (1978), Bralts (1986) and Erida (Bamdad-Machiani et al., 2014) tape was in the excellent class and drip line according to Merriam and Keller (1978), Erida (Bamdad-Machiani et al., 2014) and Capara and Scicolone (1998) was respectively in good, acceptable and high classes where these differences were due to different units of categorizing in the three above classification methods.

Table 5: Uniformity indices in both drip lines and tape irrigation systems in Kishestan Greenhouse Complex (Iran) experiment $(\mathrm{N}=3)$

\begin{tabular}{cccccc}
\hline Treatments & $\mathrm{CU}_{1}$ & $\mathrm{CU}_{2}$ & $\mathrm{DU}$ & $\mathrm{UC}$ & $\mathrm{EU}$ \\
\hline Drip lines & 91.22 & 81.4 & 86.04 & 93.24 & 84.11 \\
Tape & 97.38 & 92.45 & 95.76 & 96.72 & 95.84 \\
Significant level & $* *$ & $* *$ & $* *$ & $*$ \\
according to t-test & & & & & $*$ \\
\hline
\end{tabular}

* Significant at the level of five percents, ${ }^{* *}$ Significant at the level of one percent

EA was calculated by two methods (Sahafamin and Farshi, 1999) and (Anonymous, 2004) in both irrigation systems (table 6). The amount of EA in drip lines and tape drip irrigation calculated with the formula provided by Sahafamin and Farshi (1999) was slightly higher than those of calculated with Anonymous (2004) method being 0.104 and
$0.102 \%$ higher, so calculated EA amounts in these two method were not much different. In general, EA in tape was more than drip lines, and there is a significant difference between the two systems in both calculating methods at the level of five percent, which is due to more uniformity in tape drippers than drip lines drippers. 
Table 6: Application efficiency (EA) in drip lines and tape in Kishestan Greenhouse Complex (Iran) experiment $(\mathrm{N}=3)$

\begin{tabular}{lccc}
\hline Treatments & Drip lines & Tape & t-test \\
methods & & & \\
\hline $\begin{array}{c}\text { Sahaf-Amin and } \\
\text { Farshi (1999) }\end{array}$ & 76.54 & 87.61 & $*$ \\
Anonymous (2004) & 76.46 & 87.52 & $*$ \\
\hline
\end{tabular}

*Significant at the level of five percents

The technical evaluation in two irrigation systems showed that tape was better than drip lines in the greenhouse. As far as farmers and capital owners prefer more net profit, and also a plan should be justified in terms of its economic achievements, therefore, the economical evaluation was done. After estimating the costs, the net profit, the water productivity indices, the net present value, the internal rate of capital return and the benefit to cost ratio, appropriate system in greenhouse in terms of the technical and the economic aspects can be recommended.

The amounts of applied water, yield and WP for two systems are presented in table 7. Strawberry yields with drip lines and tape drip irrigation were measured as 3327 and $4242 \mathrm{~kg} \mathrm{ha}^{-1}$, respectively.
Strawberry yield with the tape drip irrigation was higher than the drip lines, but statistical analysis showed that there is not any statistical difference among both of the treatments. Applied water with the drip lines and the tape drip irrigation were 1873 and $2109 \mathrm{~m}^{3} \mathrm{ha}^{-1}$, respectively. Amount of applied water in both treatments was not statistically different.

However, by increasing the applied water in the tape as compared with the drip lines yield was increased. It can be seen that the effect of both irrigation systems on strawberry yield was not significant. The effect of both yield and applied water caused the increase of the WP with tape as compared with drip lines.

Table 7: Applied water, yield and water productivity (WP) in two irrigation systems in Kishestan Greenhouse Complex (Iran) experiment $(\mathrm{N}=3)$

\begin{tabular}{llll}
\hline Treatments & $\begin{array}{l}\text { Yield } \\
(\mathrm{kg} / \mathrm{ha})\end{array}$ & $\begin{array}{l}\text { Applied water } \\
\left(\mathrm{m}^{3} / \mathrm{ha}\right)\end{array}$ & $\begin{array}{l}\text { WP } \\
\left(\mathrm{kg} / \mathrm{m}^{3}\right)\end{array}$ \\
\hline Drip lines & 3327 & 1873 & 1.78 \\
Tape drip irrigation & 4242 & 2109 & 2.01 \\
t-test & $\mathrm{ns}$ & $\mathrm{ns}$ & $\mathrm{ns}$ \\
\hline
\end{tabular}

ns: not significant at the five percent level

Total revenue and BPD index are presented in figure 2 ( $a$ and $b$ ). Sales price of strawberry was considered as 3 US $\$ \mathrm{~kg}^{-1}$. The total revenues in the drip lines and the tape drip irrigation were calculated as 10082 and 12855 US $\$ \mathrm{ha}^{-1}$, respectively. The yield was higher with tape as compared with drip lines. As a result, the total revenue with tape was higher than drip lines. BPD index with drip lines calculated as 5.45 and with tape drip irrigation as 6.06 US $\$ \mathrm{~m}^{-3}$, being $11 \%$ higher with tape. The concurrent effects of both applied water and total revenue increased the BPD index with the tape as compared with the drip lines. 


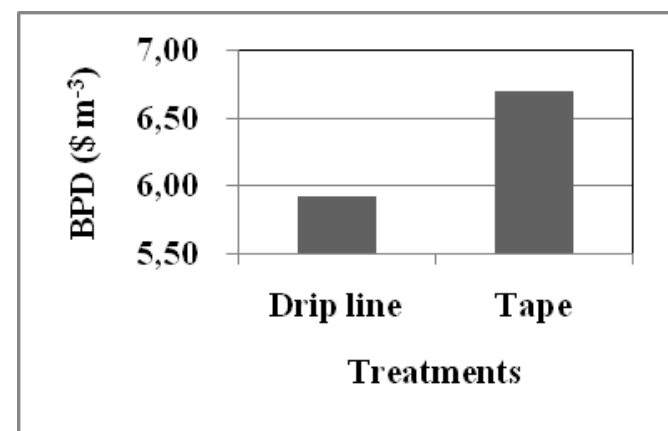

a

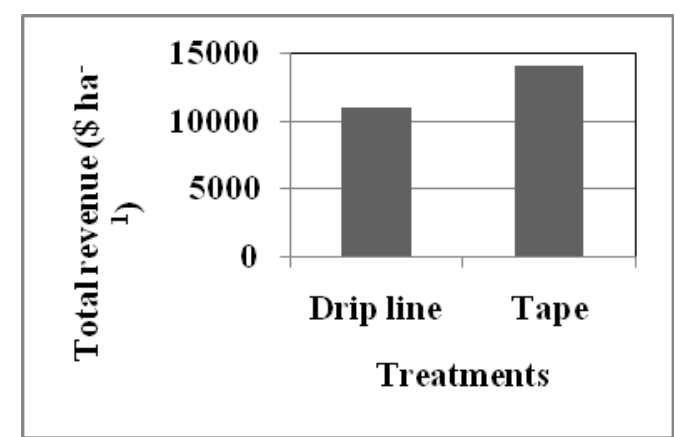

b

Figure 2: a) BPD index in drip lines and tape drip irrigation in Kishestan Greenhouse Complex (Iran) experiment $(\mathrm{N}=3)$ and $\mathrm{b})$ Total revenue (US $\$ \mathrm{ha}^{-1}$ )

As in BPD index gross profit is considered, therefore, NBPD index in which the net profit is included, is more important. The cost of central control station, installation, irrigation system operation, pipe (main and manifold), fittings and valves are the same in both irrigation systems, whereas, the costs of irrigation water and lateral (the drip lines and the tape) are different in two treatments. The cost of applied water for each cube meter was considered as 0.002 US \$ (reported by Regional Water Company). $162 \mathrm{~m}$ of tape and drip lines was used in the greenhouse. The prices of tape and drip lines were 0.55 and 2.27 US $\$ \mathrm{~m}^{-1}$, respectively.

Calculated NBPD index in both systems are presented in table 8 . It can be seen that NBPD with tape and drip lines were calculated as 5.15 and 3.94 US $\$ \mathrm{~m}^{-3}$, respectively. The NBPD with tape was higher than the drip lines because of higher total revenue with tape as well as a lower cost of irrigation water as compared with the drip lines. As a result, net profit was higher with tape than with that of the drip lines.

Table 8: Net benefit per drop NBPD index in studied two irrigation systems in Kishestan Greenhouse Complex (Iran) experiment $(\mathrm{N}=3)$

\begin{tabular}{|c|c|c|c|}
\hline Treatments & $\begin{array}{c}\text { Costs } \\
\left(\mathrm{US} \$ \mathrm{ha}^{-1}\right)\end{array}$ & $\begin{array}{l}\text { Net profit } \\
\left(\mathrm{US} \$ \mathrm{ha}^{-1}\right)\end{array}$ & $\begin{array}{c}\text { NBPD } \\
\left(\mathrm{US} \$ \mathrm{~m}^{-3}\right)\end{array}$ \\
\hline Drip lines & 87.18 & 246 & 0.13 \\
\hline Tape drip irrigation & 59.33 & 365 & 0.17 \\
\hline
\end{tabular}

Calculated net present value (NPV), IRR and B/C ratio indices are presented in table 9 for both irrigation systems. The NPV in the drip lines and tape was calculated as 33.48 and 11.17, respectively, being higher than zero in both irrigation systems, therefore, both of the systems are justified according to the economic aspects. The IRR in the drip lines and the tape was calculated as 50.61 and 47.27 which are both more than the interest rate of $22 \%$ (official rate in Iran in 2014) and showed economical justification of irrigation systems in the greenhouse. The $\mathrm{B} / \mathrm{C}$ ratio with the drip lines and tape was calculated as 1.46 and 1.21, respectively where in both of the irrigation systems is more than one, in which shows an economic justification of both of the irrigation systems. In the benefit to cost ratio method for comparison between treatments, the present value of benefits to the present value of investment ratio was calculated being 2.2. As this ratio is higher than one, so the drip line was chosen as an economical method which is in agreement with Oskounejad (2009) results. 
Table 9: Net present value (NPV), internal rate of capital return (IRR) and benefit to cost ratio (B/C) in both irrigation systems in Kishestan Greenhouse Complex (Iran) experiment $(\mathrm{N}=3)$

\begin{tabular}{ccc}
\hline Indices & Drip lines & Tape drip irrigation \\
\hline NPV & 33.48 & 11.17 \\
IRR (\%) & 50.61 & 47.27 \\
B/C & 1.46 & 1.21 \\
\hline
\end{tabular}

\section{CONCLUSION}

In this study the technical and the economical evaluations of the two drip irrigation systems i.e. the tape and the drip lines were done in a strawberry greenhouse in Kishestan Greenhouse Complex located in Some'sara, Guilan province, in the northern part of Iran. The result showed that the tape irrigation system was better in terms of the technical evaluation, whereas, drip lines were better according to economical indices. It should be said that both systems have acceptable standard level of economical and technical evaluations. Consequently, if the farmers are those who pay for the irrigation system, as they have not enough capital resource, so it is better to use tape because of lower investment costs, but if the government pays subsidy, it is better to use drip lines because of its being more beneficial. Generally, the government pays $85 \%$ of the costs to implement a pressurized irrigation system to address water resources issues in the country.

\section{REFERENCES}

Alizadeh, A. (2011). Pressurized irrigation system design. Mashhad, Iran: University of Imam-Reza publication.

Azizi, J. (2007). Economical evaluation of plan Kishestan greenhouse town in Guilan province. Policies Quarterly and Economic Research, 36, 109-133.

Ashiri, M., Hoshmand, A.A., Bromandnasab, S. (2013). Technical evaluation of drip irrigation systems of Dezful town (case study of Rajai Martyr agribusiness). Fourth National Conference on Irrigation and drainage networks management. 2628 Feb 2013. University of Ahvaz. Water Sciences and Engineering Department.

Anonymous. (2004). Technical criteria for pressurized irrigation (Designing). Technical Affairs Department. Publication no 286. Management and Planning Organization, 244 pp.

Bamdad-Machiani, S., Khaledian, M., Biglouei, M., Ashrafzadeh, A. (2014). Evaluation of drip irrigation systems in the kiwifruit gardens of east
Guilan province. Water Management in Agriculture, 1(2), 55 -62.

Bralts, V.F. (1986). Field performance and evaluation. Developments in Agricultural Engineering, 9, 216240. DOI: 10.1016/B978-0-444-42615-4.50014-X

Capara, A., Scicolone, B. (1998). Water quality and distribution uniformity in drip/trickle irrigation systems. Journal of Agriculture Engineering Research, $\quad 70, \quad 355-365 . \quad$ DOI: 10.1006/jaer.1998.0287

Cetin, B., Yazan, S., Tipi, T. (2004). Economic of drip irrigation of olives in Turkey. Agricultural Water Management, $\quad 66, \quad 145-151$ DOI: 10.1016/j.agwat.2003.10.004

Dutta, D.P. (2008). Characterization of drip emitters and computing distribution uniformity in a drip irrigation system at low pressure under uniform land slopes. MS.c. thesis. Texas A and M University.

Ghaemi, A.A., Mehdi-Hoseinabadi, Z., Sepaskhah, A.R. (2008). Water use efficiency and yield of sugar beet

Acta agriculturae Slovenica, 107 - 1, marec 2016 
under conventional and alternate tape and furrow irrigation. Water and Soil Journal, 22(2), 85-94.

Ghassemzadeh-Mojaveri, F. (1990). Field irrigation systems evaluation. Mashhad, Iran: Atan-GhodseRazavi publication.

Hanson, B.R., Bendixen, W. (2004). Drip irrigation evaluated in Santa Maria Valley strawberries. California Agriculture, 58(1), 48-53. DOI: 10.3733/ca.v058n01p48

Hasanzadeh-Arnayi, S., Fathi, P. (2012). Review of particles diameter effect on Physical Clogging particles of tape drip irrigation. Water and Soil Resources Protection, 2(3), 73-81.

Karimi, A., Homaei, M., Liyaghat, A.A., Mozardelan, M. (2004). Drip system-tape: distribution uniformity of water and fertilizer. Journal of Agricultural Research: Water, Soil and Plant, 5(2), 53-66.

Merriam, J.L., Keller, J. (1978). Farm irrigation system evaluation: a guide for management. Agency for international development, Washington, D.C.

Noshadi, M., Ghaemi, A.A. (2012). Technical and hydraulic review drip irrigation systems in Fars province. Irrigation and Drainage, 4(6), 254-264.

Oskounejad, M.M. (2009). Economical engineering or economical evaluation of industrial projects. Amirkabir University publication.

Ortega, J., Tarjuelo, J.M., Juan, J.A. (2002). Evaluation of irrigation performance in localized irrigation systems of semiarid regions. Journal of Scientific Research and Development, 4, 1-17.

Picha, D. (1999). Drip irrigation system for strawberry. Revised and approved report for publishing by ATUT/RONCO technical staff. pp 27.
Rhea, A.J., Brooker, J.R., Mundy, S.D., Eastwood, D.B., Sams, C.E. (2001). An economic analysis of sequential cropping systems in greenhouses in Tennessee: tobacco and tomatoes. Agricultural Experiment Station, University of Tennessee, Knoxville.

Sadrghaen, S.H., Akbari, M., Ashrafi, S. (2012). Review of emitter performancein subsurface drip irrigation system on hazelnut trees. Proceeding of articles abstract: first national conference of water management in the field. Research Institute of Soil and Water, Karaj.

Safi, B., Neyshabouri, M.R., Nazemi, A.H., Massiha, S., Mirlatifi, S.M. (2007). Water application uniformity of a subsurface drip irrigation system at various operating pressures and tape lengths. Turk. Agric. For., 31, 275-285.

Shojaeian, F., Ghaemi, A.A. (2010). Review of distribution uniformity water and fertilizer farm in soil level and profile in micro irrigation system. Soil and Water Conservation Research Journal, 17(1), 81-95.

Sahaf-Amin, B., Farshi, A.A. (1999). Drip irrigation (principle and design basics drip irrigation network). Publishing Agriculture, $251 \mathrm{pp}$.

Tagar, A.A., Mirjat, M.S., Soomro, A., Sarki, A. (2010). Hydrualic performance of different emitters. Park. J. Agri., Agmi. Eng. Vet. Sci., 26(2), 48-59.

Umara, B.G., Audu, I., Basher, A.U. (2011). Performance evaluation of bamboo (Oxytenanthera abyssinica) low-cost micro irrigation lateral system. ARPN Journal of Engineering and Applied Sciences, 6(5), 69-73. 